\title{
Attrition of Employees of Information Technology (It) Companies in Bangalore City
}

\author{
K. Gayathri, M. Thaiyalnayaki
}

\begin{abstract}
To manage their business in the competitive environment, management should focus on the company's internal power, this internal power is proven based on their attrition rates. Bangalore is called as IT capital of India, hundreds and thousands of people from different parts of the country come to Bangalore for their career growth and development. There are nearly 12000+ companies in Bangalore hence the possibility of employees switching companies is high and hence the HR professionals are challenged more. It becomes ineluctable for the IT companies of Bangalore to tackle high attrition rate issue. This study is to with-stand the challenges faced due to high attrition and how to address them. In this study, the opinions of 200 respondents were taken for the analysis purpose. In this research, structured questionnaire has been incorporated for collecting data and chi-square test, percentage analysis and ANOVA were used for analysis.
\end{abstract}

Index Terms: Information Technology, Attrition etc.

\section{INTRODUCTION}

Attrition is one of the ineluctable problem faced by the IT companies in the recent years. Human capital need to be considered as an important source of any industry, particularly IT industry. People tend to leave the organization voluntarily or involuntarily. In the competitive environment retaining the employees are becoming tougher task for the IT companies as they need to spend even more for filling up vacancies arising out of attrition and end up with more training cost for the prospective employees. In the recent study it is been identified that the mid experienced employees are frequently changing their jobs for high salary and other requirements.
Revised Manuscript Received on July 22, 2019.

1. K. Gayathri M.Com, M.Phil.

Research Scholar, Depart of Commerce, Vels University, Pallavaram 2. Dr. M. Thaiyalnayaki

Professor and Head of the Department- BBA, Vels University, Pallavaram

\section{ATTRITION IN GENERAL}

Attrition is also known as turnover of employees happening because of retirement, retrenchment or death of employee. Driving factors of attrition are Market i.e. better offers and options provided by competitive firms and organizations outside of IT industry.

Process - Some firms considers it as a process driven and they strongly believe that whatever improvements made still some employees will quit for some or the other reasons every year.

Thirdly it can be Stress driven because of the

unmanageable overload given for various reasons.

HR invest on analytics and researches since they wish to study the causes for employees moving out of their organization and IT environment. Attrition rate can be calculated by

$\{(\#$ of resources @ start of the year $)+(\#$ of new recruitments) - (\# of resigned resources) / Total \# of employees in the year $\} * 100$

\section{SIGNIFICANCE OF THE STUDY}

Human resources are the key assets of an Organization who supports towards the organizational strategies and goals. Human Resource Management tries to entice, uphold the right capacity and manage them well and proficiently to meet the organizational goals. People are not machines and to be managed prudently. Our study mainly emphasizes the reasons which contribute for mounting attrition rate and challenges undergone by the IT companies to retain their employees in the competitive business environment.

\section{LITERATURE REVIEW}

K Narmada, (2014) did her research titled "Indian ITES industry and employee attrition - An overview". Her major findings were that there are 3 key reasons for attrition a) career opportunity b) compensation c) personal reasons. Further she said that the attrition rate in the ITES is the highest at $17 \%$ compare to that of other industries like financial services, advertising media etc. If the mounting attrition problem is not addressed will have a negative impact on the business and IT industry.

Mr. Deepak Kumar and Dr. Ramakrishna, (2012) did their research titled 'Research on retention \& attrition '. They 
mainly found that, there are different theoretical perspectives that can be brought to bear the issue on attrition. They founded the important post-secondary attrition issues of the organizations. The major findings from their analysis, were the situations, when the employees were likely to leave the organization \& when they will return. Further, they found out the most effective strategies available to prevent frequent change over.

\section{OBJECTIVES}

- To explore the major factors causing high attrition rate in IT companies in Bangalore.

- To know why employees, leave the organization and searching out for better organization.

- To evaluate how an employee's work life balance influences his /her frequent job change over.

\section{SCOPE:}

- This study helps us to understand attrition level of workforces in IT companies in Bangalore.

- To understand the possible solutions that can help retaining the employees in the same organization.

- To study and evaluate the most important criteria in a work place.

- To understand the reasons for leaving the previous organization by the employees and in placing improvements in the current organization.

- To evaluate and understand that working environment, nature of work, organizational philosophy, salary and career progression influence the employee turnover rate.

\section{Reasons/ Issues for rise in attrition rate:}

Because of the increasing attrition rate, employees are indirectly pressurized to leave the organization. To understand better and to curve this increasing attrition rate the root causes need to be analyzed primarily.

- SALARY \& REMUNERATIONS

- LENGTHY WORKING HOURS

- NATURE OF WORK

- POOR WORK-LIFE BALANCE

- INDECOROUS EMPLOYMENT POLICIES

- LOW JOB PROFILE

- COMPETITION \& POACHING OF EMPLOYEES

- CUSTOMERS HAPPINESS

- LOSS OF SALE

\section{EFFECTS OF ATTRITION:}

When the employees are not able to accept the reasons which result in attrition, they have no other option to go in search of another better serving organization. These are adverse effects of attrition to an organization.

\footnotetext{
- INCREASED IN COST TURNOVER

- LOSS OF NAME

- REDUCED WORKFORCE QUALITY

- INCREASED WORKLOAD OF EXISTING EMPLOYEES

- REDUCED MORALE OF EXISTING EMPLOYEES
}

\section{LIMITATIONS OF THE STUDY:}

- Due to confidentiality some of the information shall not be accessed.

- Findings may wary due to some demographic factors and conditions.

- Participant' s bias is possible in some cases since this project is qualitative in nature.

- In this study sampling area is restricted only to Bangalore city.

\section{RESEARCH METHODOLOGY}

Convenience sampling method has been used by the researcher for this study. The total population are divided in to groups and the sample are collected randomly from the groups.

\section{SAMPLE SIZE: 200 respondents}

Source for data collection:

(a) Primary Data:

A well-designed questionnaire was given to IT employees in Bangalore to hoard primary data.

(b) Secondary Data:

Secondary data was hoarded through Records, Reports, and Journals.

\section{FRAMEWORK AND ANALYSIS:}

For analysis, percentages, chi-square test, one- way Anova, one sample t-test, paired sample t-test were used in the study. One sample t-test and paired sample t-test were adopted based on the formulated hypothesis. Statistical package for the social sciences (SPSS) version 20.0 was religiously used for the statistical analysis.

\section{HYPOTHESIS:}

- There is significant relationship between Attrition rate $\&$ work life balance.

- There is significant relationship between gender and stress factor.

\section{TESTING OF HYPOTHESIS: RELATIONSHIP BETWEEN ATTRITION AND WORK LIFE BALANCE:}

Null Hypothesis- H0: There is no significant relationship between attrition rate \& work life balance.

Alternate Hypothesis -H1: There is significant relationship between attrition rate $\&$ work life balance. 


\section{T-Test}

\begin{tabular}{|c|c|c|c|c|}
\hline \multicolumn{5}{|c|}{ One-Sample Statistics } \\
\hline & $\mathrm{N}$ & Mean & $\begin{array}{c}\text { Std. } \\
\text { Deviation }\end{array}$ & $\begin{array}{l}\text { Std. Error } \\
\text { Mean }\end{array}$ \\
\hline Work life balance & 200 & 4.23 & .775 & .055 \\
\hline
\end{tabular}

\begin{tabular}{|c|c|c|c|c|c|c|}
\hline \multicolumn{7}{|c|}{ One-Sample Test } \\
\hline & \multicolumn{6}{|c|}{ Test Value $=200$} \\
\hline & \multirow[b]{2}{*}{$\mathrm{t}$} & \multirow[b]{2}{*}{ df } & \multirow{2}{*}{$\begin{array}{c}\text { Sig. } \\
\text { (2-tailed) }\end{array}$} & \multirow{2}{*}{$\begin{array}{c}\text { Mean } \\
\text { Differe } \\
\text { nce }\end{array}$} & \multicolumn{2}{|c|}{$\begin{array}{l}\text { 95\% Confidence } \\
\text { Interval of the } \\
\text { Difference }\end{array}$} \\
\hline & & & & & Lower & Upper \\
\hline $\begin{array}{l}\text { Work life } \\
\text { balance }\end{array}$ & $\begin{array}{r}-3573.95 \\
6\end{array}$ & 199 & .000 & $\begin{array}{r}-195.7 \\
70\end{array}$ & -195.88 & -195.66 \\
\hline
\end{tabular}

INTERPRETATION:

The computed value is .000 . Since the computed value is lesser than the table value $(0.05)$, so discard Null hypothesis H0 \& admit Alternate hypothesis H1. Hence, imminent significant relationship between gender \& stress factor.

Therefore, Stress the most important reason for searching the better organization, depends upon the gender of the employees. Female employees face more stress and search for organizations providing peaceful working environment.

\section{DATA ANALYSIS \& INTERPRETATION: \\ PERCENTAGE ANALYSIS: INFLUENCE OF} MONETARY BENEFITS:

\begin{tabular}{|l|l|}
\hline Influence of monetary Benefits & No. of. Respondents \\
\hline Yes & 120 \\
\hline No & 80 \\
\hline Total & 200 \\
\hline
\end{tabular}

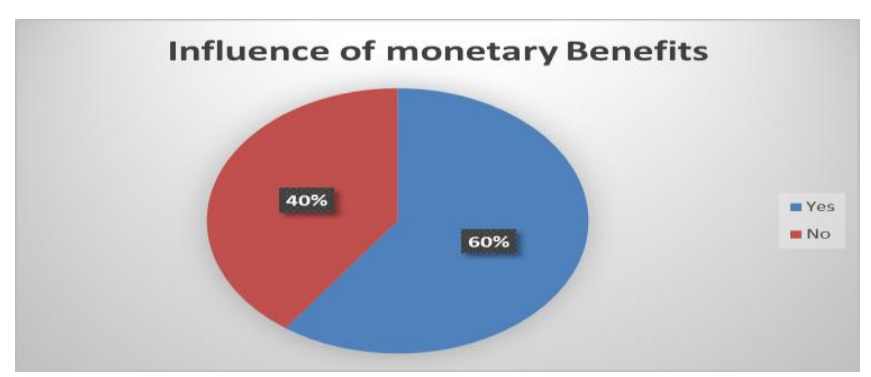

Interpretation:

From the above diagram, majority of the respondents $(60 \%)$ agreed, ultimately monetary benefits make them to influence their decisions relating to resignations and retention.

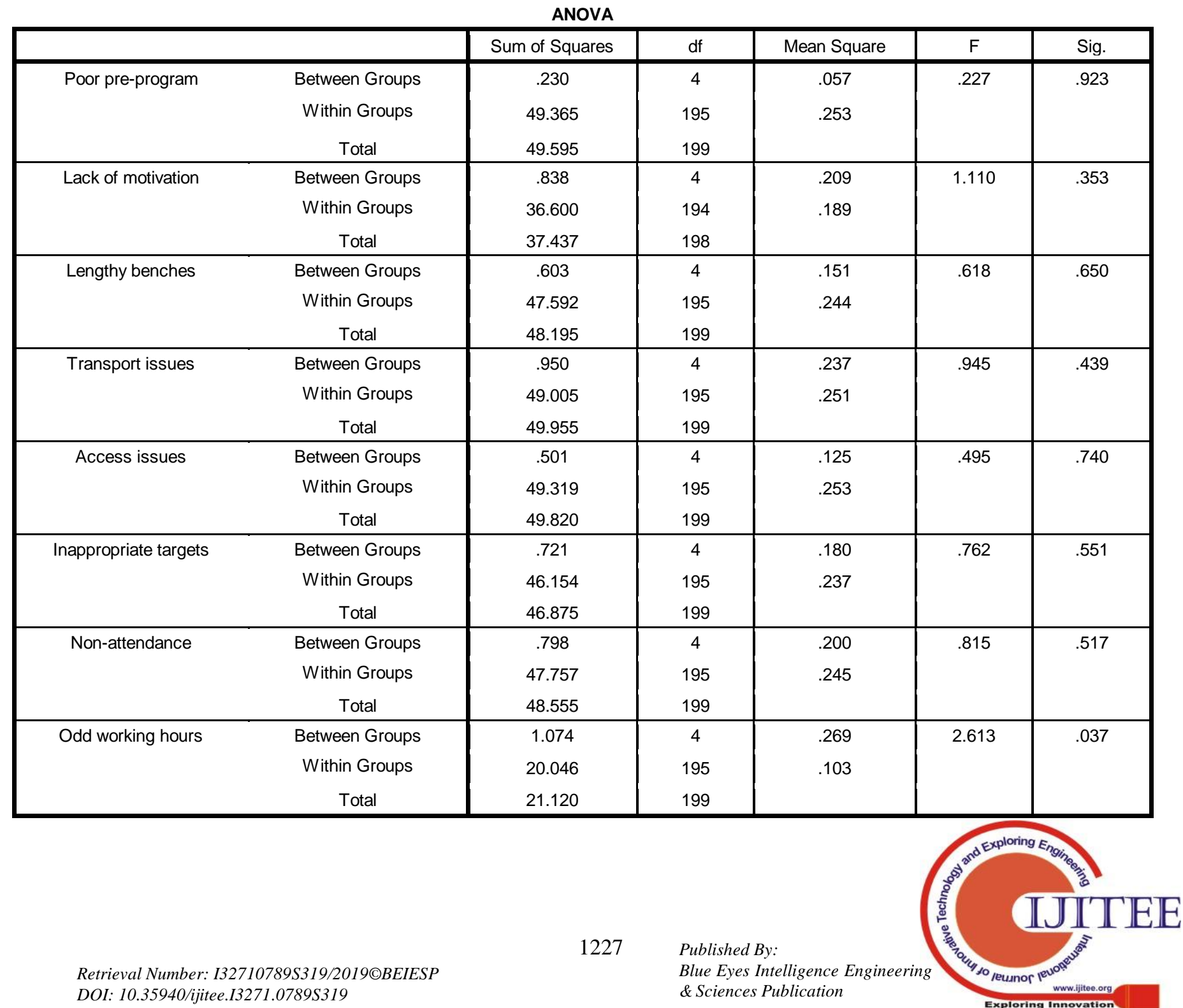




\section{ONE - WAY ANOVA ANALYSIS - REASONS FOR HIGH ATTRITION RATE AND YEARS SERVED:}

\section{INTERPRETATION:}

As stated above, it is found that, the reasons accounted for high rate of attrition in their organizations like poor preprogram, lack of motivation, lengthy bench period, transport issues, access issues, inappropriate targeting, breach for non - attendance, odd working hours are not statistically pointed at $5 \%$ level. Hence, it is decided that, there exist an association involving years served by the employees and these reasons accounting for a high attrition rate in their organization. These reasons moderately influence the attrition rate.

\section{CHI- SQUARE ANALYSIS \\ RELATIONSHIP BETWEEN SERVICE AND ON - SITE OFFERS:}

\section{Cross-tabs}

Case Processing Summary
\begin{tabular}{|l|r|r|r|r|r|r|}
\hline & \multicolumn{5}{|c|}{ Cases } \\
\cline { 2 - 7 } & \multicolumn{2}{|c|}{ Valid } & \multicolumn{2}{|c|}{ Missing } & \multicolumn{2}{|c|}{ Total } \\
\cline { 2 - 7 } & $\mathrm{N}$ & $\begin{array}{r}\text { Perce } \\
\mathrm{nt}\end{array}$ & $\mathrm{N}$ & $\begin{array}{r}\text { Perce } \\
\mathrm{nt}\end{array}$ & $\mathrm{N}$ & $\begin{array}{r}\text { Perce } \\
\mathrm{nt}\end{array}$ \\
\hline $\begin{array}{l}\text { Service * On } \\
\text { site offers }\end{array}$ & 200 & $\begin{array}{r}100.0 \\
\%\end{array}$ & 0 & $0.0 \%$ & 200 & $\begin{array}{r}100.0 \\
\%\end{array}$ \\
\hline
\end{tabular}

\begin{tabular}{|l|r|r|r|}
\hline \multicolumn{1}{|c|}{ Chi - Square Tests } \\
\hline & \multicolumn{1}{|c|}{ Values } & \multicolumn{1}{c|}{ df } & $\begin{array}{l}\text { Asymption.Si } \\
\text { g. (2-sided) }\end{array}$ \\
\hline $\begin{array}{l}\text { Pearson Chi - } \\
\text { Square } \\
\text { Likelihood Ratio } \\
\text { Linear - by - Linear }\end{array}$ & $21.935^{\mathrm{a}}$ & 16 & .145 \\
Association & 17.192 & 16 & .373 \\
N of Valid Cases & 200 & 1 & .300 \\
\hline
\end{tabular}

a. Around 12 cells (i.e $48 \%$ ) have anticipated count lesser than 5 . The minimum anticipated count is 08 .

\section{INTERPRETATION:}

As stated above, it is found that service and on-site offers are not statistically significant at 5\% level. Hence, there is a significance difference between service of the employees and on-site offers.

Therefore, service of the employees is not related to getting on-site opportunities. The new comers or fresher's get more on-site opportunities when compared with experienced employees. So, the senior employees search for a better organization which provides them better opportunities.

\section{FINDINGS:}

- Majority of the respondents (60\%) agreed that, ultimately monetary benefits makes them to influence their decisions relating to resignations and retention.

- The organizations attempt to retain their employees irrespective of their gender.

- Service of the employees are not related to getting on-site opportunities.

\section{RECOMMENDATIONS \& COUNSELS:}

The recommendations and counsels given to address the majority issues arising due to high employee attrition based on the output of our study are.

- To reduce high employee attrition, highly competitive salary packages need to be given to IT sector employees

- Providing monitory benefits to the employees could be the best way to keep them happy.

- Ensure proper work-life balance by providing the employees flexible job hours.

- Form fun clubs to deal with stress and burn outs.

- Adopt coaching rather than commanding.

- Seeking feedback from supervisors and subordinates on regular basis could help employees to stay for a longer period.

- To make sure all employees are upskilled on their respective development and career growth opportunities.

- Flexible shift options/working hours could retain more employees.

\section{CONCLUSION}

This study mainly focuses on identifying both monitory and non-monitory factors which results in high attrition rate. Providing the competitive package of salary to the employees based on the market strategies would retain and avoid majority of attrition.

It is time for the IT companies in Bangalore to change their strategies from lengthy working ours to flexible working hours. Bangalore is considered as Silicon Valley of south India however due to hectic traffic conditions employees are over stressed. Encouraging work from home option more could avoid such stress and burnouts.

Since IT industry is one of the prominent industry in Bangalore city, the IT sector should address the employee attrition problems in a fast phase for their business continuity and growth.

\section{REFERENCES}

1. Kothari.C.R, RESEARCH METHODOLOGY, Reprint Edition 2004.

2. Agarwala Tanuja, STRATEGIC HRM, Oxford University Press, Edition 2007.

3. Bhattacharyya Kumar Dipak, HUMAN RESOURCE PLANNING, Anurag Jain for Excel Books, second edition 2002. 